\title{
Role of elevated organic carbon levels and microbial activity in coral mortality
}

\author{
David I. Kline ${ }^{1,2,3}$, Neilan M. Kuntz ${ }^{2,3}$, Mya Breitbart ${ }^{2}$, Nancy Knowlton ${ }^{1,3}$, \\ Forest Rohwer ${ }^{2,4, *}$ \\ ${ }^{1}$ Center for Marine Biodiversity and Conservation, Scripps Institution of Oceanography, University of California, \\ San Diego, La Jolla, California 92093, USA \\ ${ }^{2}$ Department of Biology, LS301, San Diego State University, 5500 Campanile Dr, San Diego, California 92182, USA \\ ${ }^{3}$ Smithsonian Tropical Research Institute, Apartado 2072, Balboa, Republic of Panama \\ ${ }^{4}$ Center for Microbial Sciences, San Diego State University, San Diego, California 92182, USA
}

\begin{abstract}
Coral reefs are suffering a long-term global decline, yet the causes remain contentious. The role of poor water quality in this decline is particularly unclear, with most previous studies providing only weak correlations between elevated nutrient levels and coral mortality. Here we experimentally show that routinely measured components of water quality (nitrate, phosphate, ammonia) do not cause substantial coral mortality. In contrast, dissolved organic carbon (DOC), which is rarely measured on reefs, does. Elevated DOC levels also accelerate the growth rate of microbes living in the corals' surface mucopolysaccharide layer by an order of magnitude, suggesting that mortality occurs due to a disruption of the balance between the coral and its associated microbiota. We propose a model by which elevated DOC levels cause Caribbean reefs to shift further from coral to macroalgal dominance. Increasing DOC levels on coral reefs should be recognized as a threat and routinely monitored.
\end{abstract}

KEY WORDS: Coral reef decline - Dissolved organic carbon - Coral • Montastraea • Bacteria . Caribbean · Nutrients

\section{INTRODUCTION}

Corals and their associated biodiversity on reefs are being lost at an alarming rate. Among the most degraded reefs are those of the Caribbean, where coral cover has declined by $80 \%$ over the last $30 \mathrm{yr}$ (Gardner et al. 2003), resulting in a phase shift to algaldominated reefs (Hughes et al. 2003). Algal overgrowth associated with overfishing (Pandolfi et al. 2003) and bleaching associated with global warming (Hughes et al. 2003) are widely accepted as contributors to this catastrophic decline. Coral disease is also a major contributor to declining coral abundance (Green \& Bruckner 2000, Aronson \& Precht 2001, Sutherland 2004). In this regard, the role of deteriorating water quality remains controversial (Szmant 2002). Elevated nutrients (e.g. phosphate, nitrate, and ammo- nia) are often suggested as a major cause of reef decline, yet physiological and experimental support for this claim has been contradictory and unclear (Stambler et al. 1991, Steven \& Broadbent 1997, FerrierPages 2000, Koop et al. 2001, McCook 2001). However, water quality has many components which have not been as widely studied, such as dissolved organic carbon (DOC) and pollutants such as pesticides, oil, toxins etc.

The potential role of these other aspects of water quality are of particular interest in the context of coralassociated microbes (both Archaea and Bacteria), which are known to be diverse, abundant, and speciesspecific in some cases (Ducklow \& Mitchell 1979, Rohwer et al. 2001, 2002, Kellogg 2004, Wegley et al. 2004). Three different Caribbean species living in close proximity have been shown to have distinct bacterial 
communities, while the same coral species in distant locations have similar bacterial communities (Rohwer et al. 2001, 2002). These coral-associated Bacteria likely help to define a coral's ecological niche on the reef, and thus disruption of the microbial community could make corals susceptible to coral disease or mortality (Ducklow \& Mitchell 1979, Segel \& Ducklow 1982, Knowlton \& Rohwer 2003, Rohwer \& Kelley 2004).

Several studies have shown that there is a dramatic shift in the associated microbial community in diseased corals. Frias-Lopez et al. (2002) found that the microbial communities on 3 species of healthy Caribbean corals were strikingly different from the community on the same species of corals that had been infected with black band disease. This result suggests that disease results in a transformation of the normal coral microbial community. Further, molecular studies of Montastraea annularis corals with a white plague-like disease revealed that there exists a whole-animal response to disease, with shifts in the microbial community even healthy looking tissue (Pantos et al. 2003).

Although we know that the role of the microbial community in coral health and immunity is likely important, the specifics of this interaction remain unclear. In this study, a suite of compounds commonly associated with declining water quality were tested to determine which were most detrimental to corals. Microbial growth rate and additions were also studied to determine whether or not these components disrupted the relationship between a coral and its associated microbial community.

\section{MATERIALS AND METHODS}

Coral collection. Montastraea annularis nubbins were collected in Bocas del Toro, Republic of Panama. A hammer and chisel were used to break off the nubbins at the base, so that coral tissue was not damaged. Corals were transported to the Smithsonian Tropical Research Institute's (STRI) Caribbean marine field station in 191 buckets fitted with plastic separators to minimize coral damage. The $M$. annularis nubbins were distributed in a random block design in all experiments, with one coral nubbin from each colony used in each treatment set.

Coral ecotoxicology experiments. Experiments were conducted using the Aquatic Automated Dosing and Maintenance System (AADAMS), a custom-built, flow-through system that continually doses coral nubbins with treated seawater (Kline 2006). The AADAMS can test 40 independent treatments, with 10 replicates per treatment $(n=400)$. Coral nubbins were maintained in $100 \mathrm{ml}$ opaque plastic incubation vessels that sat in water baths at ambient reef temperatures. The AADAMS was housed in an outdoors culturing room fitted with window screens to achieve light levels similar to those measured on the reef where the corals were collected. Venturi valves in the AADAMS automatically added the treatments to incoming seawater which was delivered to the incubation vessels, replacing the coral's seawater once every $8 \mathrm{~min}$.

This study incorporates the results from five $30 \mathrm{~d}$ experiments, conducted between February and November 2003, that tested phosphate (supplied as 0.5, 2.5, $5.0 \mu \mathrm{M} \mathrm{KH}_{2} \mathrm{PO}_{4}$ ), nitrate (supplied as 1.0, 2.5, $6.25 \mu \mathrm{M}$ $\left.\mathrm{Ca}\left(\mathrm{NO}_{3}\right)_{2}\right)$, ammonia (supplied as $0.5,2.5,5.0 \mu \mathrm{M}$ $\mathrm{NH}_{4} \mathrm{Cl}$ ), 5 DOC sources (D-glucose, lactose, galactose, starch, arabinose; 5 to $\left.25 \mathrm{mg} \mathrm{l}^{-1}\right)$ and untreated seawater controls. Different combinations of treatments were run in the 5 experiments, and the results from the appropriate treatments were combined. Treatment concentrations were set according to data on polluted reefs (Table 1). The corals were also treated with naturally occurring particulate organic matter $(\mathrm{POM})$ that was concentrated from reef water using a $100 \mathrm{kDa}$ tangential flow filter and added back at $10 \times$ and $100 \times$ concentrations. POM was only added for $1 \mathrm{~h} \mathrm{~d}^{-1}$, due to logistical limitations that prevented continuous dosing.

The coral nubbins were monitored daily throughout the experiments, and pathologies (bleaching or mortality) were noted and photographed. Coral mortality was defined as the complete loss of tissue revealing bare skeleton, and mortality was scored as $25,50,75$, or $100 \%$ mortality, depending on the relative percentage of polyps that died.

Microbial growth rate experiment. Montastraea annularis coral columns $(\sim 10 \mathrm{~cm}$ in diameter $)$ were collected and placed in aerated, $40 \mathrm{l}$ glass seawater aquaria with either $2.5 \mu \mathrm{M}$ potassium phosphate, $12.5 \mu \mathrm{M}$ calcium nitrate, $25 \mathrm{mg} \mathrm{l}^{-1}$ glucose or untreated seawater (control); 4 corals were added to each glass aquarium, and all treatments were set up in duplicates, for a total of 8 aquaria ( 4 treatments in duplicates). At each time point $(1,2,4$, and $26 \mathrm{~h})$ coral surface mucopolysaccharide layer (SML) was collected with a sterile syringe from one coral in each duplicate treatment after placing the coral manually, using gloves, into $0.2 \mu \mathrm{m}$ filtered seawater (to ensure that the microbial production measured was from the SML, rather than the aquarium water). Each coral was sampled only once during the experiment, and the SML divided into 3 samples. Microbial production was determined using $\left[{ }^{3} \mathrm{H}\right.$-methyl]thymidine incorporation (Fuhrman \& Azam 1982) on the 3 SML samples from each time point. Saturation curve assays were used to determine the proper concentration of thymidine, which was $25 \mathrm{nM} \mathrm{[}{ }^{3} \mathrm{H}$-methyl]-thymidine with a $1 \mathrm{~h}$ incubation. Each SML sample was added to a $15 \mathrm{ml}$ centrifuge tube, then shaken vigorously; $1.5 \mathrm{ml}$ of SML was added to 4 (3 samples and 1 carry-over control) microfuge tubes containing $\left[{ }^{3} \mathrm{H}\right.$-methyl]-thymidine. The 
microfuge tubes were then incubated in a reef-temperature seawater table. After $1 \mathrm{~h}, 75 \mu \mathrm{l}$ of $100 \%$ trichloro acetic acid (TCA) was added to stop growth. Carry-over controls were used for each sample by adding the $75 \mu \mathrm{l}$ of TCA before incubation to determine the amount of unincorporated $\left[{ }^{3} \mathrm{H}\right.$-methyl]-thymidine that remained in the samples after processing. Samples and controls were then chilled on ice for $10 \mathrm{~min}$ and pelleted in a microfuge $(15000 \times g, 10 \mathrm{~min})$. The supernatant was aspirated away, and the pellet washed with $1.5 \mathrm{ml}$ of ice-cold $5 \%$ TCA, centrifuged again for $10 \mathrm{~min}$ and then washed with $1.5 \mathrm{ml}$ ice-cold $80 \%$ ethanol (Fuhrman \& Azam 1982). The samples and controls were centrifuged again, aspirated, resuspended in $500 \mathrm{ml}$ of bleach, and vortexed until completely resuspended. The samples and controls were then added to $20 \mathrm{ml}$ of scintillation fluid and counted on a liquid scintillation counter.

Coral-associated Bacteria augmentation experiment. Coral SML was collected with a sterile $10 \mathrm{ml}$ syringe from 3 healthy Montastraea franksi, Agaricia tenufolia, Porites astreoides and Diploria strigosa colonies in the field. Upon return to the laboratory, $100 \mu \mathrm{l}$ of each respective SML type was spread onto Luria-Bertani agar plates (LB, Sigma-Aldrich) and thiosulfate citrate bile salts (TCBS) plates (Sigma-Aldrich) and incubated at $37^{\circ} \mathrm{C}$ for $3 \mathrm{~d}$. 'Vibrios' were defined as those Bacteria that could grow on TCBS plates, whereas 'Enterics' were those Bacteria that grew on standard LB

Table 1. Nutrient and organic carbon concentrations measured on coral reefs and used in enrichment experiments. DOC: dissolved organic carbon (passed through a GF/F filter); POC: particulate organic carbon (trapped on a GF/F filter); TOC: total organic carbon (unfiltered). HTCO: high temperature combustion oxidation; WCO: wet chemical oxidation; HTCO is considered more reliable. Ideally, organic carbon analyses should be preformed using Hansel's standards. To our knowledge, only the studies by Hata et al. (2002) and Yahel et al. (2003) meet both criteria. Designation as 'polluted' is based on the relevant authors' notes. GBR: Great Barrier Reef, Australia. This table is not exhaustive

\begin{tabular}{|c|c|c|c|c|c|}
\hline Site & $\begin{array}{l}\text { Nitrate } \\
(\mu \mathrm{M})\end{array}$ & $\underset{(\mu \mathrm{M})}{\mathrm{Ammonia}}$ & $\begin{array}{l}\text { Phosphate } \\
(\mu \mathrm{M})\end{array}$ & $\begin{array}{c}\text { Organic carbon } \\
\qquad(\mu \mathrm{M})\end{array}$ & Source \\
\hline $\begin{array}{l}\text { Tumon Bay, Guam } \\
\text { (fringing reef with runoff) }\end{array}$ & $4.1-8.0$ & nd & $0.1-0.6$ & nd & Marsh (1977) \\
\hline \multirow[t]{2}{*}{ Discovery Bay, Jamaica } & nd & nd & nd & $\begin{array}{c}29-82 \\
\text { (TOC/WCO) }\end{array}$ & $\begin{array}{c}\text { Means \& Sigleo } \\
\text { (1986) }\end{array}$ \\
\hline & nd & nd & nd & $\begin{array}{l}6-66 \\
\text { (POC) }\end{array}$ & $\begin{array}{l}\text { Webber \& Roff } \\
\text { (1995) }\end{array}$ \\
\hline $\begin{array}{l}\text { Ponape and Majero Is., } \\
\text { Micronesia }\end{array}$ & nd & nd & nd & $\begin{array}{c}46-332 \\
(\mathrm{DOC} / \mathrm{HTCO})\end{array}$ & $\begin{array}{l}\text { Yoshinaga et al. } \\
\text { (1991) }\end{array}$ \\
\hline Various sites worldwide & nd & nd & nd & $\begin{array}{c}43-143 \\
\text { (DOC/various) }\end{array}$ & $\begin{array}{l}\text { Sorokin (1995) and } \\
\text { references therein }\end{array}$ \\
\hline $\begin{array}{l}\text { Florida Keys National } \\
\text { Marine Sanctuary }\end{array}$ & $0.7-4.5$ & $1.7-10.3$ & $0.3-0.8$ & $\begin{array}{c}333-1653 \\
\text { (DOC/HTCO) }\end{array}$ & $\begin{array}{l}\text { Boyer et al. } \\
\text { (1997) }\end{array}$ \\
\hline $\begin{array}{l}\text { Tuamotu Archipelago } \\
\text { (reef lagoon) }\end{array}$ & nd & nd & nd & $\begin{array}{c}58-167 \\
\text { (DOC/HTCO) }\end{array}$ & $\begin{array}{l}\text { Pagés et al. } \\
\text { (1997) }\end{array}$ \\
\hline $\begin{array}{l}\text { Palau Archipelago and } \\
\text { West Pacific }\end{array}$ & nd & nd & nd & $\begin{array}{l}3.3-5.6 \\
\text { (POC) }\end{array}$ & $\begin{array}{l}\text { Hata et al. } \\
\quad(1998)\end{array}$ \\
\hline $\begin{array}{l}\text { Guarajuba Reef, Bahia, } \\
\text { Brazil (polluted) }\end{array}$ & $2.3-12.1$ & $4.8-10.7$ & $0.1-1.6$ & nd & Costa et al. (2000) \\
\hline $\begin{array}{l}\text { Great Barrier Reef, Australia } \\
\text { (ENCORE nutrient enrichment) }\end{array}$ & nd & $\begin{array}{l}11.5-36.2 \\
\mathrm{NH}_{4} \mathrm{Cl}\end{array}$ & $\begin{array}{l}2.3-5.1 \\
\mathrm{~K}_{3} \mathrm{PO}_{4}\end{array}$ & nd & Koop et al. (2001) \\
\hline $\begin{array}{l}\text { Gould Island, Great Barrier Reef, } \\
\text { Australia (fringing reef) }\end{array}$ & nd & $0.1-0.2$ & $0.1-0.2$ & nd & McCook (2001) \\
\hline \multirow[t]{2}{*}{$\begin{array}{l}\text { Curacao Reefs, } \\
\text { Netherlands Antilles }\end{array}$} & nd & nd & nd & $\begin{array}{c}154-208 \\
\text { (DOC/WCO) }\end{array}$ & $\begin{array}{l}\text { van Duyl \& Gast } \\
\text { (2001) }\end{array}$ \\
\hline & $0.5-1.5$ & nd & $0.04-0.1$ & nd & $\begin{array}{l}\text { van Duyl et al. } \\
\text { (2002) }\end{array}$ \\
\hline Shiraho Reef, Ishigaki Is., Japan & nd & nd & nd & $\begin{array}{c}2-4.5(\mathrm{POC}) \\
60-87 \\
\text { (DOC/HTCO) }\end{array}$ & $\begin{array}{l}\text { Hata et al. } \\
\quad(2002)\end{array}$ \\
\hline Eilat, Israel & nd & nd & nd & $\begin{array}{c}79-81 \\
(\mathrm{DOC} / \mathrm{HTCO})\end{array}$ & $\begin{array}{l}\text { Yahel et al. } \\
\text { (2003) }\end{array}$ \\
\hline Panama, Caribbean Sea & $1.0-6.25$ & $0.5-5.0$ & $0.5-5.0$ & $\begin{array}{c}415-2075 \\
\left(5-25 \mathrm{mg} \mathrm{l}^{-1}\right)\end{array}$ & This study \\
\hline
\end{tabular}


plates. Three ml of sterile seawater was added to each plate, scraped with an alcohol-flame-sterilized glass spreader and then dissolved in $50 \mathrm{ml}$ of sterile seawater. A $100 \mu$ subsample from each plate was spread onto a fresh plate and grown in the incubator for the next treatment change. After $3 \mathrm{~d}$, the Bacteria from the $4 \mathrm{SML}$ plates made from the 4 coral species were scraped, and $100 \mu \mathrm{l}$ subsamples of each were combined onto $1 \mathrm{LB}$ plate and 1 TCBS plate. Plating controls were made by scraping LB and TCBS plates with sterile seawater. Bacteria concentrations were determined based on turbidity measurements using a spectrophotometer $(\lambda=$ $600 \mathrm{~nm}$ ) and a standard curve with $1 \mathrm{op}$ tical density (o.d.) $=10^{9}$ Bacteria $\mathrm{ml}^{-1}$. The cultured Bacteria were added to 301 of fresh seawater in glass aquaria once every $3 d$, to make a final concentration of $\sim 10^{6}$ Bacteria $\mathrm{ml}^{-1}$. There were $10 \mathrm{M}$. annularis nubbins in each aquaria.

\section{RESULTS}

\section{Coral mortality in ecotoxicology experiments}

Treatment of corals with phosphorus or nitrogen sources did not cause significant mortality in five $30 \mathrm{~d}$ experiments with respect to the seawater controls (Fig. 1; p > 0.1, Mann-Whitney $U$-test). Coral mortality caused by DOC treatments was on average 5-fold higher $(36.6 \%)$, and significantly different compared to controls $(p<0.001)$. Individual treatments that had significantly greater mortality compared with controls included $25 \mathrm{mg} \mathrm{l}^{-1}$ lactose ( $\left.\mathrm{p}<0.001\right)$, $25 \mathrm{mg} \mathrm{l}^{-1}$ starch $(\mathrm{p}<0.01), 25 \mathrm{mg} \mathrm{l}^{-1}$ galactose $(\mathrm{p}<0.05), 12.5 \mathrm{mg} \mathrm{l}^{-1}$ glucose $(\mathrm{p}<0.05)$ and $25.0 \mathrm{mg} \mathrm{l}^{-1}$ glucose $(\mathrm{p}<$ 0.05). Organic carbon treatments caused pathologies similar to those reported for band diseases, with a progressive loss of tissue starting at the colony margins, as well as rapid sloughing of coral tissue. Similar mortality patterns due to DOC loading were also observed in 4 previous culturing experiments using a simpler culturing system in Panama and Puerto Rico (data not shown). Naturally occurring reef POM caused significant bleaching of the corals in both treatments (Fig. 1, p < 0.005).

\section{Microbial growth rates}

After $26 \mathrm{~h}$, microbial production had increased by almost an order of magnitude on corals treated with D-glucose, and was significantly higher than in the controls $(p<0.001)$. In all of the other treatments, microbial growth rates were approximately constant and were not significantly higher than the controls ( $p>$ 0.05, Fig. 2).

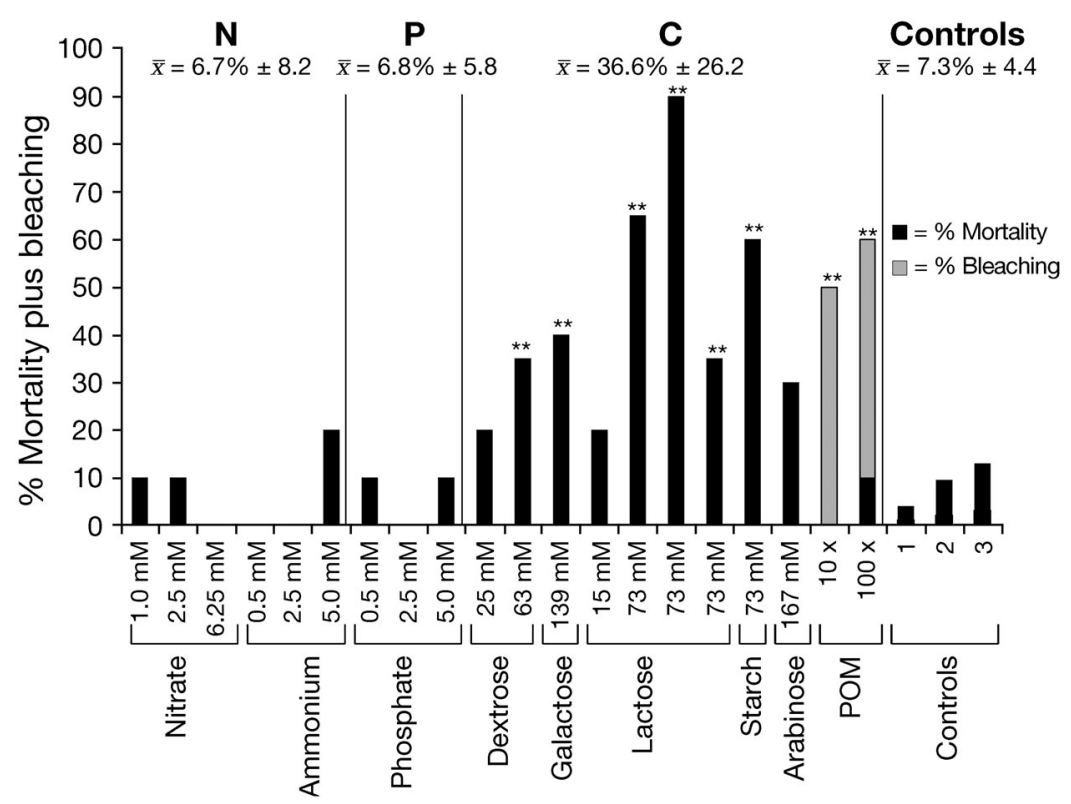

Fig. 1. Montastraea annularis. Percentage of coral mortality and bleaching (mean $\pm \mathrm{SD}$, given above) from nitrogen $(\mathrm{N}$, includes ammonium chloride and calcium nitrate), potassium phosphate (P) and organic carbon (C) additions after $30 \mathrm{~d}$. Asterisks $\left({ }^{* *}\right)$ indicate significant differences between treatments and controls $(\mathrm{p}<0.05$, Mann-Whitney $U$-test). Carbon treatments included a naturally occurring carbon source, particulate organic matter (POM)

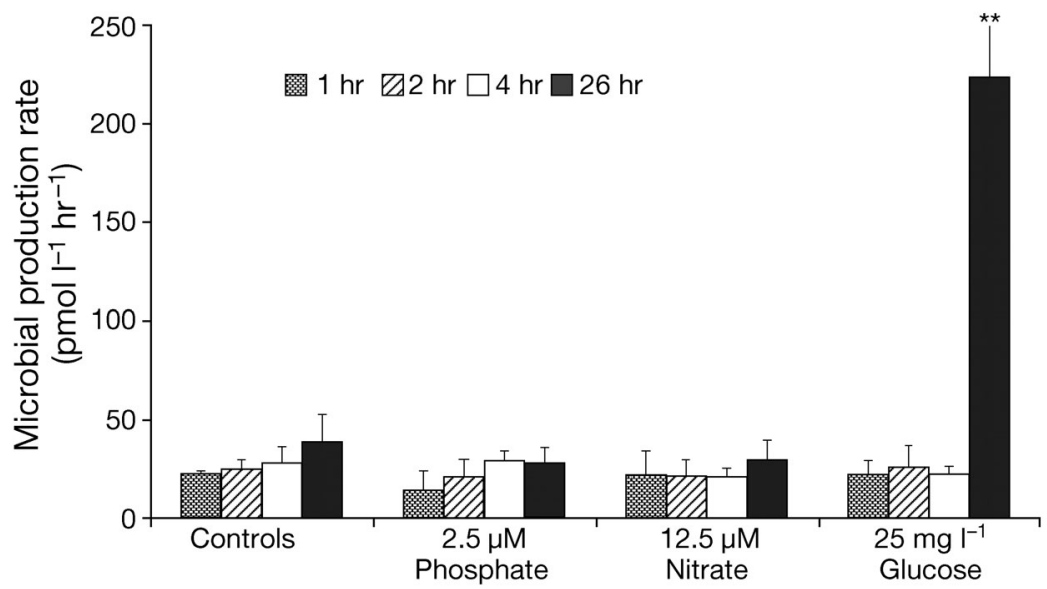

Fig. 2. Montastraea annularis. Microbial production as measured by thymidine incorporation in coral surface mucopolysaccharide layer (SML) when exposed to nitrogen, phosphorus and carbon treatments after 1,2,4 and $26 \mathrm{~h}$ of exposure $( \pm \mathrm{SD})$. Asterisks $\left({ }^{* *}\right)$ indicate that the microbial production rate was significantly greater than the controls $(p<0.001$, Mann-Whitney $U$-test) 


\section{Augmentation of coral-associated Bacteria}

Addition of $\sim 10^{6}$ microbes $\mathrm{ml}^{-1}$ of seawater in aquaria caused elevated coral mortality in aquaria experiments as compared with controls (Fig. 3). The Vibrios caused $100 \%$ mortality in $16 \mathrm{~d}$, while the Enterics caused $90 \%$ mortality in 19 d. Both the coralassociated Enterics and Vibrios had a lethal time until $50 \%$ mortality $\left(\mathrm{LT}_{50}\right.$ ) of $14 \mathrm{~d}$ (Fig. 3).

\section{DISCUSSION}

DOC is a critical substrate for microbial growth. Although many of the microbes associated with corals are found in the mucus layer, much of the mucusassociated carbon is in a refractory form that is not available for microbial growth (Herndl \& Velimirov 1986, Wild et al. 2004). Our observation that DOC loading causes significant coral mortality and increasing microbial growth rates by an order of magnitude suggests that SML-associated microbes are carbonlimited. The addition of simple sugars directly increases the amount of labile DOC, and one possibility is that it enables microbes to break down more complex and previously unavailable carbon sources via

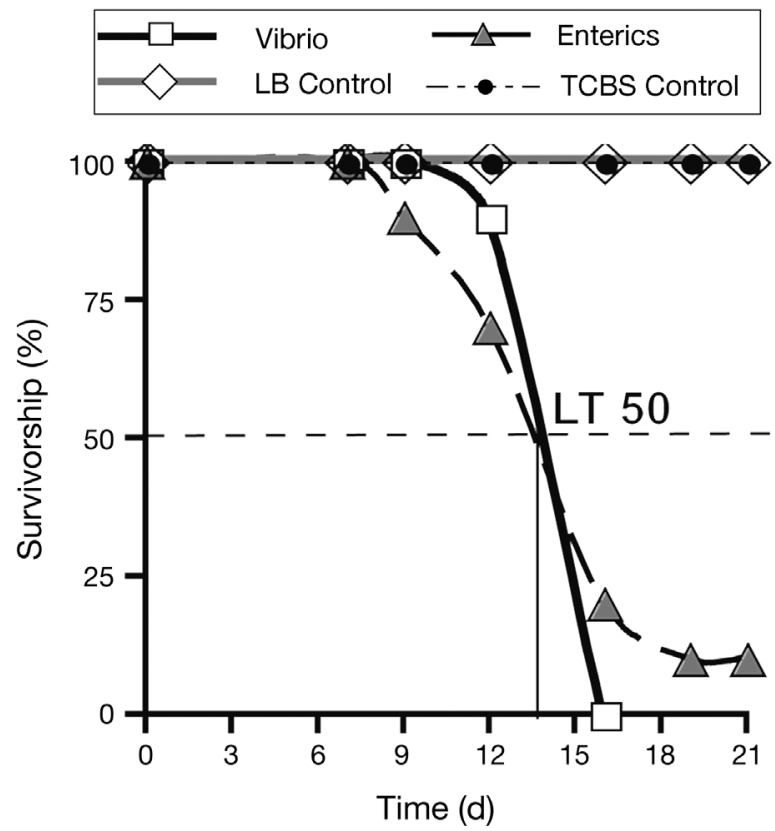

Fig. 3. Montastraea annularis. Inoculation experiments with Bacteria cultured from coral surface mucopolysaccharide layer (SML). Bacteria $\left(10^{6} \mathrm{ml}^{-1}\right)$ were added to 10 coral columns in aerated aquaria. Treatments included Enteric and Vibrio Bacteria cultured from coral SML as well as LB and TCBS culture media controls. The $\mathrm{LT}_{50}$ is the time required to kill $50 \%$ of the corals co-metabolism (Azam et al. 1993). Healthy corals actively control the growth rate of their associated microbes (Ducklow \& Mitchell 1979, Breitbart et al. 2005), and DOC additions may disrupt the normal mechanisms of control. Elevated microbial growth rates likely cause coral death by oxygen depletion, accumulation of poisons (e.g. hydrogen sulphide or secondary metabolites) and/or microbial predation on weakened coral polyps (Segel \& Ducklow 1982).

Due to logistic limitations, microbial growth rate experiments were only run for $26 \mathrm{~h}$. With more time, the microbial growth rates on the coral would likely reach an equilibrium as the populations grew to a level that the coral could no longer withstand. The explosive growth after only $26 \mathrm{~h}$ suggests that high levels of DOC rapidly disrupt the balance between the coral and its associated microbes. In support of this hypothesis, Kuntz et al. (2005) showed that continual exposure to elevated DOC leads to an exponential increase in coral mortality.

Addition of Bacteria cultured from the coral SML directly killed corals. The addition of $\sim 10^{6}$ microbes $\mathrm{ml}^{-1}$ approximately doubles the number of Bacteria that the coral is exposed to, because there are normally $\sim 10^{6}$ microbes $\mathrm{ml}^{-1}$ of seawater (Moriarty et al. 1985). However, the diverse and abundant microbial community on corals is fairly evenly distributed taxonomically (Rohwer et al. 2002), and these treatments likely enriched a subset of the community. This could disrupt the balance between the different Bacteria, possibly leading to overgrowth of a member of the community and subsequent coral mortality. Another possibility is that enrichment of a subset of the community allows these Bacteria to outcompete other Bacteria that could have important defensive (i.e. antibiotic production) or metabolic roles (i.e. carbon or nitrogen fixation).

The vast majority of coral disease incidences occur on reefs with medium-to-high anthropogenic impacts (Green \& Bruckner 2000). Our findings suggest that increasing DOC levels from sewage and organic waste associated with coastal populations could contribute to the high incidence of disease on highly polluted reefs. Pathologies observed with organic carbon additions (a sloughing off of coral tissue often initiating at the coral edge) confirm this supposition, because they were similar to those of known coral diseases (Sutherland et al. 2004). Furthermore, our experiments with naturally occurring carbon sources revealed that POM concentrated 10 to $100 \times$ from reef water caused significant bleaching. Bleached corals are likely to be more vulnerable to disease, suggesting that lower levels of DOC caused coral stress in the form of bleaching, while higher levels lead to mortality.

Other human activities can indirectly raise organic carbon levels on reefs. Removal of herbivores by over- 


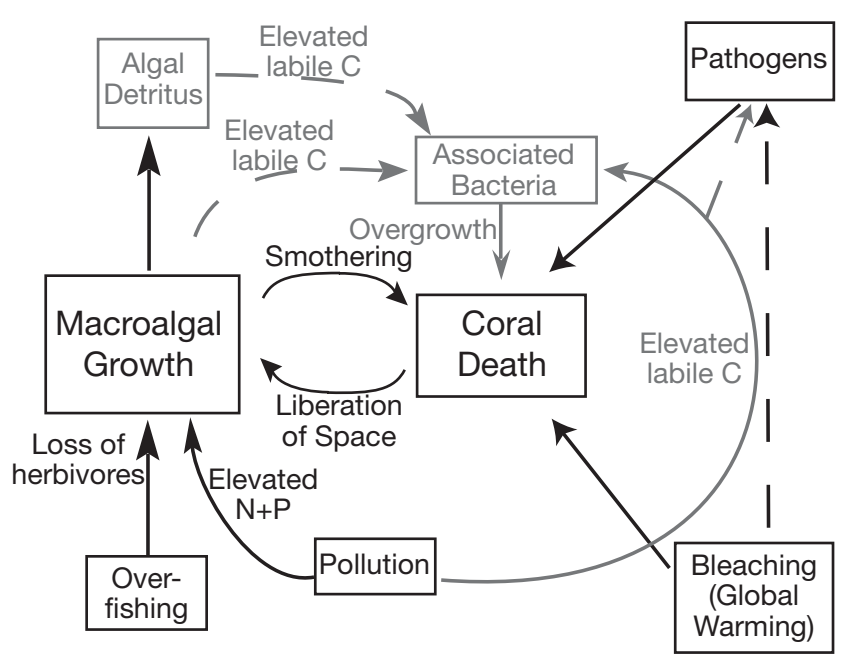

Fig. 4. Proposed role of dissolved organic carbon (DOC) in amplification of a positive feedback loop involving the coral-macroalgal competitive balance. Previous studies (shown in black) concentrated on the impacts of overfishing, and nitrogen and phosphorus pollution in promoting macroalgal growth. This research (shown in grey) highlights how eutrophication and macroalgae increase organic-carbon loading and may lead to microbial growth and coral mortality

fishing, aggravated in the Caribbean by an epizootic of the sea urchin Diadema antillarum (Lessios et al. 1984), has led to increasing amounts of macroalgae. Algal growth is promoted by increasing nitrate and phosphate levels (Hatcher \& Larkum 1983, Littler \& Littler 1984, McManus \& Polsenberg 2004). Because macroalgae release labile DOC from both living and dead tissue (Khailov \& Burlakova 1969), increasing coverage by macroalgae could also contribute to mortality by increasing DOC and thus causing overgrowth of the SML-associated microbial community. The dead coral can then serve as substratum for further macroalgae growth, resulting in additional increases in DOC and a positive feedback loop (Fig. 4) that could rapidly lead to a phase shift from coral to macroalgal dominance.

Current management and monitoring protocols almost never measure organic carbon. Our results show that organic carbon must now be recognized as a threat to coral reefs and should be considered in coral monitoring and management plans.

Acknowledgements. We thank the Smithsonian Tropical Research Institute (STRI); the staff of STRI's Caribbean field station in Bocas del Toro Panama for logistical support; and the Government of Panama for the permission to collect corals and work in Panama (Autoridad Nacional del Ambiente, Departamento de Cuarentena Agropecuaria del Ministerio de Desarollo Agropecuaria). Thanks go to Ernetso Weil for logistical support in Puerto Rico; the staff of the University of
Puerto Rico's La Parguera Caribbean field station; S. Sandin and C. Hsieh for assistance with statistical analyses; and S. W. Chisholm, J. B. C. Jackson, M. Newman, S. Sandin, E. Sala, F. Azam, V. Vacquier, M. Haygood, G. Paredes, L. McClenachan, J. Flowers and S. Walsh for reading and providing important feedback on the manuscript. This research was supported by NSF OCE 01-37748 and the Gordon and Betty Moore Foundation Marine Microbial Initiative (F.R.) and Scripps Institution of Oceanography start-up funds to N.K. A National Defense Science and Engineering Graduate (NDSEG) Fellowship, a Smithsonian Pre-doctoral Fellowship, and a UCSD Tinker Fellowship provided additional research and salary support to D.I.K.

\section{LITERATURE CITED}

Aronson R, Precht W (2001) White-band disease and the changing face of Caribbean coral reefs. Hydrobiologia 460:24-38

Azam F, Smith DC, Steward GF, Hagström Å (1993) Bacteriaorganic matter coupling and its significance for oceanic carbon cycling. Microb Ecol 28:167-179

Boyer JN, Fourqurean JW, Jones RD (1997) Spatial characterization of water quality in Florida Bay and Whitewater Bay by multivariate analyses: zones of similar influence Estuaries 20(4):743-758

Breitbart M, Bhagooli R, Griffin S, Johnston I, Rohwer F (2005) Microbial communities associated with tumors on Porites compressa. FEMS Microbiol Lett 243:431-436

Costa OS Jr, Leão ZMAN, Nimmo M, Attril MJ (2000) Nutrification impacts on coral reefs from northern Bahia, Brazil. Hydrobiologia 440:307-315

Ducklow HW, Mitchell R (1979) Bacterial populations and adaptations in the mucus layers on living corals. Limnol Oceanogr 24:715-725

Ferrier-Pages C, Gattuso JP, Dallot S, Jaubert J (2000) Effect of nutrient enrichment on growth and photosynthesis of the zooxanthellate coral Stylophora pistillata. Coral Reefs 19:103-113

Frias-Lopez J, Zerkle AL, Bonheyo GT, Fouke BW (2002) Partitioning of bacterial communities between seawater and healthy, black band diseased, and dead coral surfaces. Appl Environ Microbiol 68:2214-2228

Fuhrman JA, Azam F (1982) Thymidine incorporation as a measure of heterotrophic bacterioplankton production in marine surface waters: evaluation and field results. Mar Biol 66:109-120

Gardner TA, Cote IM, Gill JA, Grant A, Watkinson AR (2003) Long-term region-wide declines in Caribbean corals. Science 301:958-960

Green EP, Bruckner AW (2000) The significance of coral disease epizootiology for coral reef conservation. Biol Conserv 96:347-361

Hata H, Suzuki A, Maruyama T, Kurano N, Miyachi S, Ikeda Y, Kayenne H (1998) Carbon flux by suspended and sinking particles around the barrier reef on Palau, western Pacific. Limno Oceanogr 43(8):1883-1893

Hata H, Kudo S, Yamano H, Kurano N, Kayanne H (2002) Organic carbon flux in Shiraho coral reef (Ishigaki Island, Japan). Mar Ecol Prog Ser 232:129-140

Hatcher BG, Larkum AWD (1983) An experimental analysis of factors controlling the standing crop of the epilithic algal community on a coral reef. J Exp Mar Biol Ecol 69:61-84

Herndl GJ, Velimirov B (1986) Microheterotrophic utilization of mucus released by the Mediterranean coral Cladocora cespitosa. Mar Biol 90:363-369 
Hughes TP, Baird AH, Bellwood DR, Card M and 13 others (2003) Climate change, human impacts, and the resilience of coral reefs. Science 301:929-933

Kellogg C (2004) Tropical Archaea: diversity associated with the surface microlayer of corals. Mar Ecol Prog Ser 273: 81-88

Khailov KM, Burlakova ZP (1969) Release of dissolved organic matter by marine seaweeds and distribution of their total organic production to inshore communities. Limnol Oceanogr 14:521-527

Kline DI, Bryant J, Kisflaudy E, Rohwer G, Nostropaur F, Grayson J, Knowlton N, Rohwer F (2006) The Aquatic Automated Dosing and Maintenance System (AADAMS). Limnol Oceanogr Methods (in press)

Knowlton N, Rohwer F (2003) Multispecies microbial mutualisms on coral reefs: the host as a habitat. Am Nat 162:S51-S62

Koop K, Booth D, Broadbent A, Brodie J and 16 others (2001) ENCORE: The effects of nutrient enrichment on coral reefs. Synthesis of results and conclusions. Mar Pollut Bull 42:91-120

Kuntz N, Kline D, Sandin S, Rohwer F (2005) Pathologies and mortality rates caused by organic carbon and nutrient stressors in three Caribbean coral species. Mar Ecol Prog Ser 294:173-180

Lessios HA, Robertson DR, Cubit JD (1984) Spread of Diadema mass mortality through the Caribbean. Science 226:335-337

Littler MM, Littler DS (1984) Models of tropical reef biogenesis: the contribution of algae. Prog Phycol Res 3:323-363

Marsh JA Jr (1977) Terrestrial inputs of nitrogen and phosphorus on fringing reefs of Guam. Proc 3rd Int Coral Reef Symp 2:331-336

McCook LJ (2001) Competition between corals and algal turfs along a gradient of terrestrial influence in the nearshore central Great Barrier Reef. Coral Reefs 19:419-425

McManus JW, Polsenberg JF (2004) Coral-algal phase shifts on coral reefs: ecological and environmental aspects. Prog Oceanogr 60:263-279

Means JC, Sigleo AC (1986) Contribution of coral-reef mucus to the colloidal organic pool in the vicinity of Discovery Bay, Jamaica. Bull Mar Sci 39(1):110-118

Moriarty DJW, Pollard PC, Hunt WG (1985) Temporal and spatial variation in bacterial production in the water column over a coral reef. Mar Biol 85:285-292

Pages J, Torreton JP, Sempere R (1997) Dissolved organic carbon in coral-reef lagoons by high temperature catalytic

Editorial responsibility: Otto Kinne (Editor-in-Chief), Oldendorf/Luhe, Germany oxidation and UV spectrometry. C R Acad Sci Ser II A Sci Terre Planetes 324(11):915-922

Pandolfi JM, Bradbury RH, Sala E, Hughes TP and 8 others (2003) Global trajectories of the long-term decline of coral reef ecosystems. Science 301:955-958

Pantos O, Cooney R, Le Tissier M, Barer M, O'Donnell A, Bythell J (2003) The bacterial ecology of a plague-like disease affecting the Caribbean coral Montastraea annularis. Environ Microbiol 5:370-382

Rohwer F, Kelley ST (2004) Corals as microbial landscapes. In: Rosenberg E, Loya Y (eds) Coral health and disease. Springer, Berlin, p 265-277

Rohwer F, Breitbart M, Jara J, Azam F, Knowlton N (2001) Diversity of bacteria associated with the Caribbean coral Montastraea franksi. Coral Reefs 20:85-95

Rohwer F, Seguritan V, Azam F, Knowlton N (2002) Diversity and distribution of coral-associated bacteria. Mar Ecol Prog Ser 243:1-10

Segel LA, Ducklow HW (1982) A theoretical investigation into the influence of sublethal stresses on coral-bacterial ecosystem dynamics. Bull Mar Sci 32:919-935

Sorokin Y (1993) Coral reef ecology. Springer, Berlin

Stambler N, Popper N, Dubinski Z, Stimson J (1991) Effect of nutrient enrichment and water motion on the coral Pocillopora damicornis. Pac Sci 45:299-307

Steven ADL, Broadbent AD (1997) Growth and metabolic responses of Acropora palifera to long-term nutrient enrichment. In: Lessions HA, Macintyre IG (eds) Proc 8th Int Coral Reef Symp, Balboa 1:867-872

Sutherland KP, Porter JW, Torres C (2004) Disease and immunity in Caribbean and Indo-Pacific zooxanthellate corals. Mar Ecol Prog Ser 266:273-302

Szmant AM (2002) Nutrient enrichment on coral reefs: is it a major cause of coral reef decline? Estuaries 25:743-766

Wegley L, Yu Y, Breitbart M, Casas V, Kline DI, Rohwer F (2004) Coral-associated Archaea. Mar Ecol Prog Ser 273:89-96

Wild C, Huettel M, Klueter A, Kremb SG, Mohammed Y, Rasheed M, Jorgensen B (2004) Coral mucus functions as an energy carrier and particle trap in the reef ecosystem. Nature 428:66-70

Yahel G, Sharp JH, Marie D, Hase C, Genin A (2003) In situ feeding and element removal in the symbiont bearing sponge Theonella swinhoei: Bulk DOC is the major source for carbon. Limnol Oceanogr 48(11):141-149

Yoshinaga I, Fukami K, Ishida Y (1991) Comparison of DNA and protein-synthesis rates of bacterial assemblages between coral-reef waters and pelagic waters in tropical ocean. Mar Ecol Prog Ser 76(2):167-174

Submitted: June 9, 2005; Accepted: December 8, 2005

Proofs received from author(s): April 29, 2006 